\title{
Street Children: Concept, Causes, Consequences and Alternative Coping Strategies in Ethiopia
}

\author{
Issa Hassen \\ Department of Sociology, Collage of Social Sciences and Humanities, Madda Walabu University, P.O. Box 246, \\ Bale-Robe, Ethiopia
}

\begin{abstract}
Street children problem is a global phenomenon, and it has created countless problems to millions of children in all parts of the world. Street children exist on the margins of society, living in inhumane conditions, suffering from hunger, harassment and physical abuse, deprived of basic services such as education and health care. Understanding the problem of street children and solving their problem is very crucial. However, the problems of street children are poorly understood by policy makers, academicians and development actors. Therefore, the objective of this paper was to review available literature on the socio economic conditions of street children, their difficulties and actions taken to mitigate the problems by multiple agencies in Ethiopia. Furthermore, available coping strategies are also discussed.
\end{abstract}

Keywords: Causes, consequences, solution, street children, Ethiopia

DOI: $10.7176 /$ RHSS/9-17-02

Publication date:September $30^{\text {th }} 2019$

\section{Introduction}

The problem of children living on the street is a global phenomenon. It has created countless problems to millions of children in all parts of the world (UNICEF, 2007). They live a transitory life style and lack basic necessities like food, health care, and a safe place to stay. In the world, street children exist on the margins of society, living in inhumane conditions, suffering from hunger, harassment and physical abuse, deprived of basic services such as education and health care (Shimelis, 2015). On the street they frequently survive by begging, stealing or working in the informal sectors in low paying jobs (Zena and Aneth, 2010). Consequently they faced different challenges while striving for their survival. The most complex challenge faced by children in the streets was dealing with the perceptions of those around them and the treatment they consequently afforded (Shimelis, 2015).

One of the major social problems encountered by different nations worldwide is that of homeless or street children. The circumstances and experiences of street children, including abuse of sexual and physical from other children, sleeping on pavement, and engaging in survival activities, which in most cases bordered on criminality, astounded the present researcher. On the basis of these, it can be claimed that street children cannot benefit from the modern developments due to the unequal adaptation to economic development of countries. Children are one of those disadvantageous groups. Among children, the ones who work or live on street are one of the outcomes of this unequal adoption.

There are millions of children in the world's streets; most of them deprived of their childhood opportunities of becoming socialized in a pro-social institution, such as a school (Ward and Seager, 2010). Although estimating the exact number of street children is difficult, UNICEF reports that tens of millions of children are on the streets worldwide and probably the number is increasing (UNICEF, 2005). Similarly, in Ethiopian context, many people who visit urban centers are troubled by the presence of children on the streets. Yet, not much attention and awareness of the plight of the children has been generated.

Compared with Latin America and Asia, the problem of street children is a comparatively new phenomenon in Africa. Sub-Saharan Africa is currently the least urbanized region of the developing world with less than 30 percent of the population living in cities and towns. It is currently experiencing the highest urban growth rates in the world. Local authorities in Africa are increasingly confronted with a rising number of street children (UMP, 2000). Although the issue of street children is a worldwide phenomenon, it is even more serious in developing nations where lack of adequate social infrastructure and socio-economic program threatens the developmental needs of these unfortunate children. Similar to many least developed countries, the rapidly growing number of street children is becoming most critical socio-economic problem urban Ethiopia is facing today. In Ethiopia, children form a sizeable segment of the population. According to CSA (2007), there were more than 40 million children in Ethiopia in 2007. Many thousands of children live under especially difficult circumstances (Meseret, 1998).

According to Kibrom (2008), children in Oromia constituted $46 \%$ of the total population where $11.6 \%$ of them are homeless children. Of the total homeless children in the region, about $66 \%$ lived in urban Oromia while the remaining 34\% lived in rural Oromia. Atakilte and Gunilla (2011) stated that Shashemene Town as a commercial center has recently attracted many migrants, particularly from the densely populated Southern 
Nations, Nationalities and Peoples' Region (SNNPR) in search of work and for a better life. With the continued growth of the town, there has been a growth in the number of children on the streets. Many of whom are attracted to the town for the same reason as the adults, with the hope for good income generating possibilities. There are no recent and accurate statistics to ascertain the exact number of street children although UNICEF putsat 1,107 (UNICEF, 2000). Understanding the problem of street children and solving their problem is very crucial. However, the problems of street children are poorly understood by policy makers, academicians and development actors. Therefore, the objective of this paper was to review the socio economic conditions of street children, their difficulties and actions taken to mitigate the problems by multiple agencies in Ethiopia.

\section{Concept of Street Children}

The most common definition of a street child was formulated by Inter-NGOs in Switzerland in 1983: "Any girl or boy who has not reached adulthood, for whom the street (in the broadest sense of the word, including unoccupied dwelling, wasteland etc.) has become her or his habitual abode and/or source of livelihood, and who is inadequately protected, supervised or directed by responsible adults" (Sweta et al., 2000). UNICEF distinguishes between "children of the street" and "children on the street". Children of the street are homeless children who live and sleep on the streets in urban areas. For these children, family ties may exist, but they are tenuous and maintained occasionally. Children on the street earn their living or beg for money on the street and return to their home at night. They are likely to handover all or part of their earnings to the family, thus, contributing to the economic survival of the family unit. The parents often encourage their being in the streets. The distinction between the two groups is important because children on the street have families and homes to go to, whereas children of the street are alone and lack the emotional and psychological support normally provided by parents (UNICEF, 2001).

While the concepts of "children of the street" and "children on the street" usefully and reflect the different circumstances children are living under, the complexity of the phenomenon means that overlaps and grey areas remain. The activities of the children of the street and the children on the street are often similar, while the extent to which the children have contact with their family varies considerably. Some children of the street are abandoned and rejected by their families; other children of the street left their family due to prevailing circumstances, but maintain regular contact and may visit the family for a while before returning to the street. Meanwhile, the category of children on the street includes a grey area of children who sometimes sleep on the streets and sometimes sleep at home. There are also children within this category who are staying with distant relatives or employers. Children on the street often live in poor households, and many of these children are candidates for becoming children of the street. Although, it may be helpful to maintain these two main categories, it is important to acknowledge that there is great variation in the living arrangements and family situation of both categorizations of children (Muchini, 2001).

\section{Factors Contributing for the Streetism of the Children}

The motives for children leaving their homes have been well documented by various authors. (Issa and Madelyn, 2018; Mandoyu, 2018). This section critically evaluates the conceptions of street children which have emerged throughout the literature. The problem of street children has be fallen one of the urban problems which call for the attention of the global community.

The existence of street children is a worldwide phenomenon and is directly related to social network instability, poverty and ensuing rural-urban migration (MGLSD, 1999). Family breakdown is another major cause for streetism (Issa and Madelyn, 2018; Mandoyu, 2018). Muchini (2001) points out that family disruption are highly prevalent among families with poor economic conditions. The urbanization process involves ruralurban migration. The migrant families overwhelmed with multiple adversities are unable to support their families in which case, children are forced to join street life for better chance of survival (Eade, 1995). Hence, broken family, urban poverty and migration are brought forth as militating factors which precipitate children to the street. The other studies and reports also focused on the street children phenomenon in countries of Latin America, Asia and Africa, tend to draw attention to a number of factors seen to be behind the appearance and growth of the phenomenon. Generally, these factors are mainly socio-economic in nature (Kibrom, 2008).

By and large, there are three factors causing the street children problem to emerge. At micro level, the causes can be identified from the related children and family and also the independent cause like escape from the family, asked to work after school or have been dropped out, adventuring, playfully or asked by friend. At mezzo level, the causes are derived from family such as neglected by parents' incapability of providing basic needs, rejected by parents, maltreatment or domestic violence, difficulty of communicating with family/neighbor, separated from parents, wrong attitude to the child, limitation of child caretaking pushing the children to have physical, psychological, and social problems. Meanwhile at macro level, the causes identified includes: among poor people, children are asset to help family improvement, they are taught to work leading to dropping out of school, while in other societies, the street children are prospect criminals (Demartoto, 2012). 
Neglecting and arbitrariness against the children, relative to their family's poverty, is also related to parental rejection. Lewis (1961) suggested the theory of parental rejection which explained the neglect against children. He also explained that the father or mother who rejects children is related to the low moral support of society.

One right of children, including the street children, is to enjoy the right to be educated. But, education sustainability for the street children generates apprehension (Demartoto, 2012). Meanwhile, education is the means of preparing the children to live within the society (Ballantine, 2001). Durkheim suggests that education has different tone from one society to another and from one age to another. But in addition to such difference, there is also similarity in which education plays a part in bringing about and in maintaining the social order and social equilibrium (Durkheim, 1961). In addition, education plays a part in socialization, selection, distribution and social integrity processes. Society holds a dominant position in creating an individual into a member of society. Parsons and Bales (1955) see education as the socialization and selection functions holder.

However, out of these two functions, the one more emphasized is socialization function encompassing value, cognition, and motor aspects. Among these three aspects, there is a consensus that value is a factor presupposed to the emergence of and maintenance of social integrity. Through socialization, the cultural value the society has is converted into the applied or internalized one by the member of society individually. Blackledge and Hunt (1985) explains that Durkheim's education model gives dominant position to the teacher as the representative of state, nation and adult in preparing the young generation to become a complete member of society. Otherwise, he puts the students in the created position. In this way, homogeneity and the society's sustainability as well as social order is maintained. It is believed that in a balanced society, all members of which have collective consciousness. Education functions and serves to create consensus over this values (Demartoto, 2012).

Education should be applied consistent with the characteristics of society or community including the street children in order that education can function and play a role in the society, particularly, in coping with the street children's problems. In the presence of education, it is expected that the street children can play a role in bringing about and maintaining social order and social equilibrium (Silva, 1996).

Street children face a situation in which their rights as a child are getting reduced, whether in education, life sustainability, growth, or protection aspect. They are very vulnerable to the negative effects of the street environment. Thus, many of them have social deviation. Street children are frequently identified as a free, wild, incompliant with rules and a child committing negative activities such as stealing, quarreling, drinking alcohol, drugs abusing and involving in free sex (Berman, 1996).

Although each child has his/her own experience that drove him/her to the streets, lack of educational sustainability of street children, parents are also one of the factors that lead to streetism. As Ali (2004) stated in spite of attempts to eliminate illiteracy, there remain high levels of illiteracy among the families of street children. As a result of their lack of education, parents may be unaware of the importance and value of education and may not provide appropriate educational care for their children. This situation encourages children to drop out of school and remain in the streets. Often, the family does not resist this action. In some cases, the family is the main factor that drives children from school.

In the case of Africa, many factors have contributed to the increased poverty levels in many African countries. Poverty has precipitated an increase in the demand for families to allow their children to engage in economic activities to supplement the household income. According to Aptekar (1994), most children are in the streets because of poverty. Mufune (2000) also posits that being on the street is a public disclosure of destitution. As has been stated by many writers, the structure of the African family system has undergone tremendous changes. For instance, Mufune (2000) estimates that change in the family structure have occurred largely due to factors of modernization.

Similar to other experiences of African countries, socio-economic factors have significant place in leading children to the street in Ethiopia (HCS, 1997).According to the same organization, it identified poverty and death of parents pushing almost $85 \%$ of children in Dire Dawa Town to streetism.

In agricultural societies, drought and famine may be to blame. Family disruption, in the form of death, separation, and divorce, has shrunk family size still further, often resulting in poor, single parent, female-headed households. This leaves children vulnerable, and with the general absence of community and governmental support, they have few options in times of crisis other than life on the street (Neil Swan, 1995).

A comparative study conducted in Awassa by Solomon et al. (2002) revealed that higher number of street children than non-street children have more than six siblings. In the contrary, $42.8 \%$ of the non-street children have less than three siblings as opposed to the street children group, which are only $29.6 \%$. In 1995 , Yemane claimed that $51.8 \%$ of the street children in Adama have 4-7 siblings. In the same town, $55.1 \%$ of fathers and $59 \%$ of mothers of street children were illiterates (Yemane, 1995). Migration from rural to urban areas is also one of the factors that increase the problem of streetism in towns. According to a study conducted by Solomon et $a l$ in 2002 in Awassa, their findings showed that about $61.1 \%$ of street children were migrants from other rural or urban areas in Ethiopia (Solomon et al., 2002). 
The literature highlighted above, provides social network instability, poverty and ensuring rural-urban migration, modernization which tremendously change family system experience, and family breakdown under the three main factors-micro level, mezzo level and macro level as the cause of street children's problem to emerge. But the reviewed literature still did not focus on reintegration of street children to society. Thus, this study also considered the issue of reintegration by convincing that all concerned body besides the factors mentioned in the literature to fill the gaps of research on the issue.

\section{Challenges Facing Street Children}

Among the most complex challenges that street children face are physical abuse, sexual abuse, mental and emotional abuse, health problem, child labor, juvenile delinquency and children trafficking. The details of these difficulties are discussed here under:

Physical abuse is the violent acts which do not happen accidentally, which is forbidden, that cause pain to child, constantly damages child's development and functionality (UNICEF, 2006). As a result of physical abuse; ecchymoses, injuries, edemas, scars, burns, scars might occur because of being scald, and retardation in physical development (Ezgi, 2008). According to Makope (2006), fresh and younger children in the streets are at the mercy of bullying by older boys and girls who demand anything inclusive of money, food, sex and clothes. Those children, who cannot stand, live a sad life, especially when counting money or eating as crew leaders can snatch the money or food by force. Seniority is then acquired through tenure in streets and through fighting. These seniors or crew leaders have lost interest in changing their lives that they hardly leave the streets. Age tends to influence the risks of violence to which street children are exposed and their responses to violence (Benitez, 2007). Thus, younger street children face more violence. It has been observed that street boys tend to replicate violence as aggressors (Raffaelli, 2000).

Street children are usually involved in sexual behavior at a very young age, and are often exposed to the risky activities associated with premature sexual exposure (Bourdillon, 2003). Makope (2006) stated that $98 \%$ of street girls lose virginity once they enter into the street as they lack advice from parents, and imitate experienced female street children. Ruparanganda (2008) referred female street children as "an underclass of the underclass" because boys want them to be financially and materially disempowered so that they can have sex with these girls without any resentment. Thus, they are ruthlessly sexually abused and raped. Apparently, Ruparanganda observed that female street children watch haplessly as their male counterparts fight each other to have sex with them without their consent and referred to these boys as 'beasts'. These female street children described their male counterparts as beasts judging from the way they sexually abused them (Ruparanganda, 2008). Anarfi and Antwi (1995) suggested that sex among street children is very frequent and mainly for survival.

According to a report presented by the African Child Policy Forum (ACPF), a prominent child-advocacy group, "...one in every two [Ethiopian] girls is a victim of unwanted sexual touching" and "one in every two girls will marry before their 18th birthday" (IRIN, 2006). Child prostitution has been cited amongst the most pressing problems that need to be tackled in efforts to protect the girl child in Ethiopia (The Protection Project, 2005). Poverty, desperation and the obligation to support them through sex work keeps street girls within a vicious cycle, which carries with it the high risk of HIV/AIDS and STDs infection.

Generally, the prominent reasons for sexual abuse/exploitations among street children are "the child's vulnerability or dependency in terms of health, hunger, lack of proper counseling and guidance from parents. These children may not recognize the exploitation as they receive food, clothes, money, medicine, love and care in return, things that have been denied by their own parents and society at large" (Preeti, 2010).

Street children are largely deprived of nurturing and support from families, as well as the opportunities for learning and social development in school. These children have a high likelihood of developing cognitive dysfunction, learning difficulties, and emotional disorders (Densley, 2000).UNICEF gives the definition of mental abuse and neglect: it is the act of slandering child's capacity, eligibility, and constantly slandering of her/his desires, isolating the child from social relations and resources, frightening the child with superstitious beliefs, threatening with leaving the child, and demanding more things from a child that she/he can really give (UNICEF, 2007).

Other researches such as Ezgi (2008) shows that rejection, degrading, isolation, scarring, threatening, manipulation to commit crime, exploiting and denying emotional responsiveness is typically the behaviors of mental abuse and neglect. Apart from sexual and physical abuse, mental abuse creates lack of self-esteem, becoming distant from the family, love lessness, and unresponsiveness. In further cases, a child might turn to violence or she/he gets introvert. For the case of street children, both of the reactions are observed. The moment children begin to live on the street; risk of being hurt gets higher. Child gets away from family life; she/he cannot get love and start to work in marginal jobs or even they tend to commit crime (Ezgi, 2008). Although it is difficult to get information about any kind of abuse, it is argued to be affective for children to decide living on street.

Street children worldwide, including those in Ethiopia, face significant health risks from unsanitary and 
unhealthy living conditions. Bathing in polluted rivers, scavenging among large trash piles, eating dirty food, drinking contaminated water and sleeping outside without mosquito nets all increase risk for infectious diseases among this population, particularly pneumonia, tuberculosis, skin infections, gastrointestinal infections and malaria. Street children are also at high risk for sexually transmitted diseases, including HIV, due to multiple sexual partners, low rates of condom use, and having sex while under the influence of drugs or alcohol (Scanlon, 1998). Due to these health risks, street life has significant health consequences. Street children suffer from poor health outcomes because of their lifestyle, living environment, and lack of access to medical and social services (Densley, 2000).

Child labor is a problem faced in many developing countries and the harrowing experiences of affected child reeks of gory stories of road accidents or inhuman treatment (such as the chopping of hands, starvation or bathing with oil or hot water) meted out by their 'madams' and their present guardians. Even more disheartening is the fact that child labor has escalated to the level where young children are used for money making rituals (UNICEF, 2006).Street children are probably the most visible face of child labour. They lack occupational safety, work long hours, are paid no or a low wage, and work in dangerous environments. Most of them are involved in petty trade or carrying goods, shoe shining, begging, or collecting garbage (NPA, 2010).

The work carried out by street children is defined as child labour by international conventions. There are three international conventions regulating child labour: the International Labour Organization (ILO) 138 Minimum Age Convention, the ILO 182 Worst Form of Child Labour Convention, and the UN Convention on the Rights of the Child. ILO Convention 138 defines 15 years as the minimum age for admission to employment (14 years in developing countries). Children above 13 years (12 years in developing countries) may carry out light work, while the minimum age for carrying out hazardous work is 18 years (UNICEF, 2002).

Juvenile delinquency is a serious issue around the world. In Ethiopia, it is even more important, because it is often linked to the widespread use of child labor as means of increasing family income, and because some children and teenagers may seek to obtain extra income through illegal activities. It has been found that children from disadvantaged families are more likely to engage in delinquent behaviors. At the same time, children from disadvantaged families are more likely to be neglected and abused (Mersky \& Reynolds, 2007). Actually the criminogenic influence of familial disruption may vary by circumstances (Kierkus and Hewitt, 2009). In addition, theoretical constructs drawn from social control and learning theories (Apel \& Kaukinen, 2008) may help explain why family structure is related to misbehavior.

However, contextual factors (e.g., family, friends, neighborhoods activities) also play a significant influential role in preventing adolescent drug use and delinquent behaviors such as stealing, attacking someone with a weapon or gang fighting (Brooks-Gunn et al., 2007). Moreover, contextual factors have been found to serve as protective factors against temperamental risks (Valois et al., 2002). Thus, neighborhood safety, parental monitoring and physical activity are examined as potential moderators as these variables target community, familial, and extracurricular environments of the individual which are believed to interact with individual characteristics and have been shown to be related to child delinquency (Lynam et al., 2000). That is, adolescents' higher status socio-economic backgrounds, parental support, and GPAs predicted lower levels of drug use and antisocial behavior, Children living in disadvantaged neighborhoods are at risk for school dropout, teenage births, internalized symptoms, and behavioral disorders (O'Neil et al., 2001).

One of the key components of neighborhood disadvantage is crime/safety, which is believed to impact mental health. Aneshensel and Sucoff (1996) found that in a large sample of adolescents, the perception of neighborhood safety influenced their behavior such that more threatening neighborhoods were associated with increased symptoms of oppositional defiant and conduct disorders. The neighborhood disorder model posits that neighborhood incivilities, such as vandalism, street harassment and gang presence, impact residents' fear of crime, which in turn is associated with subsequent increases in crime and juvenile delinquency (Wandersman and Nation, 1998).

Harsh, inconsistent discipline and poor supervision in early childhood can contribute to the development of conduct problems putting children at risk for peer rejection and academic failure, which then lead to associating with deviant peers and ultimately results in delinquency (Patterson et al., 1989). Monitoring has been consistently found to moderate delinquent peer influences on children's subsequent delinquent behaviors by buffering the effects.

The United Nations General Assembly (UNICEF, 2002) defines trafficking as the illicit and clandestine movement of persons across national and international borders, largely from developing countries and some countries with economies in transition with the end goal of forcing women and girl children into sexually or economically oppressive and exploitative situations for the profit of recruiters, traffickers, crime syndicates, as well as other illegal activities related to trafficking, such as forced domestic labor, false marriages, clandestine employment and false adoption.

A large number of street children suffer from different types of inhuman abuses and exploitations as a result of trafficking within Ethiopia. However, reliable and comprehensive data on the emergence and development of 
trafficking in children as well as the number of children who have fallen victim in country trafficking are not available, especially regarding street children (Ebigbo, 2006). The impact of trafficking of children and street children has been identified to be loss of lives, increase in prevalence of STDs, including HIV/AIDS, increase in violence and crime rate, increase of school dropouts, impaired child development, poor national image, and massive deportation of girls from developing countries.

According to 2007 UNICEF report, street children seem to have a propensity to abuse psychoactive drugs to counteract the effects of pain and hunger. Muchini (2001) observes that the drugs, as well, reduce feelings of shame that the street children can do any job without any worry when their survival hangs in balance. Makope (2006) suggested that drugs help these street children get away from stresses and unhappiness. When sober, street children always think and worry about how they can change their circumstances. Street children's vulnerability to sexual abuse is closely linked with the high rate of drug addiction and alcohol abuse. In order to cope with stress, hunger, emotional and physical pain, and as a vehicle to become "a part" of a group, street children frequently turn to drugs and alcohol (Samson, 2010).

Drug addiction is a common element in sex trafficking, both as a mechanism for traffickers and abusers to subdue the victims and as means for victims to escape reality and "cope" with abuse (ECOSOC, 2005). As Samson (2010) stated that addiction to drugs leads some street children to "accept" sexual abuse or exploitation for money to buy more drugs. Street children suffer tremendous emotional and physical damage as this destructive cycle of self-medication, drug dependency, and sexual abuse evolves into daily life (Samson, 2010).Substance abuse undermines physical health. For example, chronic alcohol abuse is associated with diseases of the liver, central nervous system, and heart. Often, as in the case of the brain disorder Korsakoff's syndrome, the damage resulting from alcohol abuse is irreversible (Prince, 2006). Street children are among the first victims of these diseases.

The street children stand the risk of being arrested under the vagrancy laws. A vagrant is a person without a settled home or regular work who wanders from place to place and lives by begging. Since, such aimless wanderers can be suspected of danger to the peace and order of the society, the vagrancy laws are made to deal with people who are being able-bodied, having no visible means of subsistence and among other things, are found in or upon a premise under private ownership, without the permission of its owner or possessor or a person with authority on the property (Article 4 of Vagrancy Proclamation, 2004; Article 477 of Criminal Code, 2004). Since the street children are most of the time seen wandering aimlessly in the street, and their chances of being used in the hands of other criminals are high, they are at a risk of being suspected and arrested under vagrancy laws.

\section{Interventions to Address the Problems of Street Children}

The street children issue can best be addressed through preventive programs and policies that will strike at its social and economic causes. Special protection measures are also needed to increase development opportunities for young person's currently suffering the hardships of street life. An intervention is a purposeful action taken to influence a given situation (Fraser et al., 2009). Particularly in social work, intervention refers to steps taken by a qualified practitioner to modify an aspect of an individual, group or communities behavior, as part of an overall strategy to help them solve or reduce a problem or function better in some area of their lives. Concerning the interventions in the lives of children in general, and the street children in particular, there are two broad dimensions, namely; need based and right based interventions (FASCW, 2001).

Through time, the need/ charity based approach for intervention on children recognized as unsuccessful in bringing sustainable change (Theis, 2004). As a result, a change in the approach of the service delivery was considered necessary. Globally, this change was directly associated with the ratification of the CRC in 1989. The CRC has been ratified by almost all countries of the world, including Ethiopia. Accordingly, the convention provides a rights-based framework for intervention in the lives of children, including street children. In line with this, the convention establish universal standards for children rights to dignity, freedom from discrimination, survival, development, protection, and participation, with overall consideration given to the best interests of the child (Ennew, 2003).

Within the right based framework, interventions in the lives of the street children may take two major approaches, namely; human development and service based interventions (Ennew, 1994). The two approaches differ from one another basically on the duration and strategies they pursue. The human development approach is focused on a long term perspectives that concentrate in developing the skills and confidence of the children so as to reintegrate them into the mainstream of society. To this end, the approach utilizes strategies like providing non formal education and vocational trainings for the street children; reintegrating the children to their families, schools and the labor market; and involving family and the community in the interventions (Ennew, 2003). On the other hand, the service based approach is focused in providing a short term services to fulfill the immediate needs of the children and to protect them from danger, abuse and exploitation. This may include providing food, shelter, health services, and shorter-term training and counseling opportunities in drop-in centers (Ennew, 1994). 
However, responding to the immediate needs and situation of street children is important. It should be considered as only as a short-term solution. If not, services provisions, like food shelter and clothes through continuous charitable handouts, will make street life more bearable for the children. Besides, it will also create dependency of the children on the organizations (Volpi, 2002). Furthermore, such kind of interventions may not help the children to address their problems sustainably. Therefore, in order to make the benefits of interventions sustainable, both should be kept balanced; providing a short term solution (services for the children) on the one hand and working to promote human development on the other. Such regulative role, keeping the balance of these interventions, is usually among the dominion of governments.

\section{Major Actors to Address Problems of Street Children}

In order to address the problems of street children, a number of actors have been involved directly or indirectly. These actors include governments, NGOs, community based organizations and faith based organizations. Any all-inclusive response to the problems of street children requires the mobilization of these actors side by side with the local communities, private actors, the family and the children themselves (Kopoka, 2000).

From legal perspectives, the duty of coordinating and supervising these interventions is hugely remained under the dominion of governments both at national and local level (West, 2005). However, as experience indicates in most developing countries, governments are either incapacitated or reluctant to be involved in conducting interventions and supporting or supervising the efforts of other actors (Kopoka, 2000).

To ensure the well-being of the society the government has responsibility to formulate social welfare policy. Formulating social welfare policy for street children is also the initial task of government to tackle the problem in a manageable way. Concerning the issue of street children, the policy alternative may possibly have both the remedial as well as the proactive elements. In such cases, priority will be given to the remedial approach in order to address the existing problem of the children. However, a simultaneous effort has to be made to include the proactive elements of the welfare policy side by side with the remedial approach. The combinations of the two will help to address the problem of child streetism sustainably (West, 2005).

In most cases, national governments are too distant to observe and address the problems of street children effectively. Assessing the extent and causes of local problems affecting a city, like streetism and attempting to provide a solution for such kind of problems usually rests beyond the capacity of national governments. In such cases, local governments are best placed to understand the problem in detail (West, 2005). This is because many intervention areas pertaining to street children rehabilitation usually fall within the realm of local government responsibilities.

Any interventions to address the problems of street children might be initiated by both governmental and nongovernmental actors. However, without the municipal support, all the NGOs efforts will not address the problem sustainably (Vanderschueren et al., 1996). This means the municipality involvement has a vital role in determining the success of the interventions. This might be due to three basic reasons. Firstly, the municipalities possess formal structures which persist over time. Secondly, municipalities are the main conduit for national and international initiatives and have the power to mobilize local resources. Thirdly, municipalities act as a political center which obtains its legal authority from the national government (UMP, 2000).

When governments are preoccupied with other 'more important issues', the task of dealing with the problem of the street children will be largely left for non-governmental organizations (West, 2000). Children are not always able to speak for themselves or to assess their own needs. NGOs have a responsibility to ensure that the short-term and long-term interests of children are effectively addressed in any relief and development programme (Eade et al., 2000). Non-governmental organizations are playing a very important role in promoting the welfare of disadvantaged children by planning, financing, managing and providing advice and counseling services for various projects set up to help poor children in general and street children in particular (Dessale, 1998).

In Ethiopia, children welfare responsibilities and overseeing the implementation of various programmes targeted at mitigating the problem of street children in especially difficult circumstances has been given to MOLSA. Since the economy of Ethiopia is not strong enough to generate resources for the needed social investment, assistance from both local and international NGOs are essential to alleviate the various problems revolving around destitute children (Hope enterprise, 1997). In this regard, a number of NGOs are coming to the fore to work on child rights and to fulfill the needs of children.

According to a report on the implementation of CRC in Ethiopia (2005), more than sixteen NGOs were involved in addressing the problem of street children throughout the country. A local NGO has been providing transit shelter to protect street girls from being exposed to sexual abuses. The programme mainly focuses on provision of temporary shelter, washing facilities, counseling, education and family reunification. Ethiopia in general and Oromia in particular at the moment are enjoying the benefit of NGO projects despite variation in space and time (Regassa, 2001).

Community-level programs in the sample focus on job creation, education, advocacy among 
relevant stakeholders, the improvement of school and other basic services, and the rise social capital. To help overcome negative stereotypes, they also call for greater awareness of the problems and risks faced by street children, and of the reasons why they are in this situation. Promising programs are ones that identify and strengthen the network of community resources available for street children and that train community members who play a significant role in a child's life, such as the police, shop owners, health staff, and teachers (Elena, 2002).

To sum up, the problems of street children has become one of the major social problems in urban areas of the developing countries. To address the problem, various interventions have been made by different actors including the government, NGOs and community based organizations. The approaches and the scope of their interventions vary from one another. Traditionally, the welfare/need based approach were the dominant path to provide services for children, including the street children. However, with the ratification of the CRC, the right based approach for child programming has got wide range of acceptance in conducting interventions for children. Furthermore, the Convention also provides a framework of policy formulation to promote the right and welfare of a child. In line with this, the local governments/municipalities also have a responsibility of addressing the problems of street children in their realm.

\section{Conclusion}

From the above review it is known that poverty, death and separation of parents, lack of families' regular income, peer pressures and lack of basic social amenities are the pushing factors for the streetism of children. Physical abuse, sexual abuse, mental and emotional abuse, health problem, child labor, juvenile delinquency and children trafficking are among the most complex challenges that street children are facing.

The street children issue can best be addressed through preventive programs and policies that will strike at its social and economic causes. Special protection measures are also needed to increase development opportunities for young person's currently suffering the hardships of street life. Interventions in the lives of the street children may take two major approaches, namely; human development and service based interventions. The two approaches differ from one another basically on the duration and strategies they pursue. The human development approach is focused on a long term perspectives that concentrate in developing the skills and confidence of the children so as to reintegrate them into the mainstream of society. The approach utilizes strategies like providing non formal education and vocational trainings for the street children; reintegrating the children to their families, schools and the labor market; and involving family and the community in the interventions. Service based approach is focused in providing a short term services to fulfill the immediate needs of the children and to protect them from danger, abuse and exploitation. This may include providing food, shelter, health services, and shorter-term training and counseling opportunities in drop-in centers.

Based on this review the following recommendations were forwarded:

* In order to address the problems of street children, a number of actors have been involved directly or indirectly. These actors include governments, NGOs, community based organizations and faith based organizations.

\& Any all-inclusive response to the problems of street children requires the mobilization of these actors side by side with the local communities, private actors, the family and the children themselves.

* From legal perspectives, the duty of coordinating and supervising these interventions is hugely remained under the dominion of governments both at national and local level.

* However, when governments are preoccupied with other 'more important issues', the task of dealing with the problem of the street children will be largely left for non-governmental organizations. To ensure the well-being of the society the government has responsibility to formulate social welfare policy.

4 Formulating social welfare policy for street children is also the initial task of government to tackle the problem in a manageable way.

* Concerning the issue of street children, the policy alternative may possibly have both the remedial as well as the proactive elements.

4 The combinations of the two will help to address the problem of child streetism sustainably.

$\$$ Any interventions to address the problems of street children might be initiated by both governmental and nongovernmental actors. Integration of biological practices with physical structures is highly recommended for the rehabilitation of degraded lands.

\section{Conflict of Interests}

The authors have not declared any conflict of interests.

\section{Acknowledgments}

I sincerely show gratitude to my beloved wife Mrs Hayat Jemal for her endless support and encouragement. I 
also thanks to all my colleagues who were supporting me by giving constructive ideas.

\section{References}

ACPF, 2007a. Assessment Conducted On Child Focused Actors In Adama City Providing Support Service For Victims And Vulnerable Children.

Anarfi, J, K., \&Antwi, P., 1995. Street youth in Accra city: Sexual networking in a high-risk environment and its implications for the spread of HIV and AIDS. Health TransitionReview, Supplement to Volume 5, 131-151

Aneshensel, C. S., \&Sucoff, C. A., 1996. The neighborhood context of adolescent mental health. Journal of Health and Social Behavior, 37, 293-310.

Aptekar, L., 1994. Street Children in the Developing World:A Review of Their Condition. Cross CulturalResearch Journal, 28(3), 195-224.

Atakilte Beyene and Gunilla Bjeren, 2011.The socio-political dynamics of Brokers of new migrant labor in Shashemene, Ethiopia Paper to be presented at ECAS 2011 - 4th European Conference on African Studies, African Engagements.

Ballantine, J. H., 2001. The Sociology of Education: A Systematic Analysis. New Jersey: Prentice Hall.

Beauchemin, E., 1999. The Exodus: The Growing Migration of Children from Ghana's Rural Areas to the Urban Centers. CAS \& UNICEF.

Benitez, S.T., 2007. State of the word's street children: Violence. London: Consortium for Street Children.

Berman, L., 1996. Interaction between street children, the State and Society. Proceedings International Conference on Street Children, Bangi Malaysia: Penerbit UKM (University Kebangsaan Malaysia).

Blackledge, D., \& Hunt, B., 1985. Sociological Interpretations of Education. London: Croom Helm.

Bourdillon, M.F.C., 2003. Poor, harassed, but very much alive: An account of street people and their organization. Gweru, Zimbabwe: Mambo Press.

Brink, B., 2001.Working with Street Children: Reintegration Through Education, Support for Learning, 2001, Vol.16, No: 2:79-86.

Brooks-Gunn, J., Duncan, G. J., Klebanov, P. K., \&Sealand, N., 2007. Do neighborhoods influence child and adolescent development? American Journal of Sociology, 99, 353- 395.

Demartoto, A., 2012. Need-Based Street Children Management in Surakarta City of Central Java Province of Indonesia, Asian Social Science Journal; Vol. 8, No. 11; 2012

Densley, K., 2000. Street Children: Causes, consequences, and innovative treatment approaches. Global Health Issues, 15, 217-225.

Dessale Ayalew, 1998. The Situation of Street Children and the Role of NGOs in Meeting Their Needs. The Case of Addis Ababa.Unpublished MA Thesis in RLDS.AAU.

Durkheim, E., 1961. Moral Education: A Study in the Theory and Application of Sociology of Education. New York: The Free Press.

Duyan, V., 2005. Relationships between the Socio-demographic and Family Characteristics, Street-life Experiences and the Hopelessness of Street Children's Childhood, Vol.12 (4)

Eade, D. and Williams.S., 1995.The Oxfam Handbook of Development and Relief.Vol.1.Oxfam. UK.

Ebigbo, P.O., 2006. A profile of Child Trafficking in Nigeria, Enugu: Fourth Dimension

ECOSOC, 2005.Report submitted by the special rapporteur on the sale of children, child prostitution and child pornography, Juan Miguel Petit, on his mission to Romania. United Nations.

Elena, V., 2002.Street Children Promising Practices and Approaches: The International Bank for Reconstruction and Development/The World Bank 1818 H Street, N.W. Washington

Ennew, Judith (1994). Street and Working Children: A Guide to Planning (DevelopmentManual4). London: Save the Children.

Ennew, Judith (2003). Working with the Street Children Exploring Ways for ADBAssistance.Asian Development Bank: Regional and Sustainable DevelopmentDepartment.

Ezgi, P., 2008. A Sociological Profile of Street Children in Ankara.M.A. Thesis, Middle East Technical University, Ankara, Turkey.

FASCW, 2001.Best Practice in Working with the Street Children in Kenya: Guidelines and Interventions in Professional Practice. Nairobi: Kenya.

Fraser, Mark, Jack Richman, Maeda Galinsky and Steven Dayetal., 2009.Intervention Research: Developing Social Programs. New York: Oxford.

HCS, 1997.Survey on the Situation of Street Children and the Attitude of Commercial Enterprise Owners on Training and Job Placement of these Children in Dire Dawa town.

Hope enterprise, 1997. Best Interests of the Child-A Quarterly Publication of Hope Enterprise. Vol.1 No.1. Addis Ababa

Issa H. \& M.R. Manus, 2018. Socio-economic conditions of street children: The case of Shashemene Town, Oromia National Regional State, Ethiopia 
IRIN, 2006.Abuse of girls widespread: Selected Region Report,East Africa, Nairobi.

Jenks, C., 1996. Childhood.Routledge, London and New York.

Kibrom Berhe, 2008. Life in The Streets of Adama: The Situation of Street Children in a Fast Growing Ethiopian Town; Addis Ababa University.

Kidd, S.A., 2003. Street Youth Coping and Interventions, Child and Adolescent Social Work Journal, Vol.20 (4):235-261.

Kidist Negash, 2007.Survival Strategies of Street Children and High Risk Behaviors towards HIV/AIDS in Adama Town (Unpublished MA thesis).

Kierkus, C. A., and Hewitt, J. D., 2009. The Contextual Nature of the Family Structure/Delin uency Relationship. Journal of Criminal Justice, 37, 123-132.

Kopoka, P., 2000. The Problems of street children in Africa: An Ignored Tragedy. Paper Presented on an International Conference on Street Children and Street Children's Health in East Africa, in Dare-Salaam, Tanzania.

Lewis, O., 1961. The Children of Sanchez, New York: Random House

Lynam, D. R., Caspi, A., Moffit, T. Wikstrom, P. Loeber, R., \& Novak, S., 2000. The interaction between impulsivity and neighborhood context on offending: The effects of impulsivity are stronger in poorer neighborhoods. Journal of Abnormal Psychology, 563- 574.

Mandoyu Gemede, 2018. The Cause Consequences and Coping Strategies of Streetism in Shashemene Town; Robe Teacher's Training College.

Makope, V., 2006.A Zimbabwean street story.Harare: German Agro Action.

Mekonnen M (2011). Street Children in Addis Ababa: Exploring Policy Framework for Interventions, Addis Ababa University.

Mersky, J., \& Reynolds, A., 2007. Child maltreatment and violent delinquency: Disentangling main effects and subgroup effects. Child Maltreatment, 12, 246-258.

Meseret Tadesse, 1998. Homeless Children in Ethiopia.FSCE-Addis Ababa.

Muchini, B., 2001. A Study on Street Children in Zimbabwe.Retrieved April 5, 2013, fromhttp://www.unicef.org/evaldatabase/index_23256.html.

Mufune, M., 2000.Street Youth in Southern Africa. International Social Science Journal 52:

Neil Swan, 1995. Links between AIDS and Drug Abuse.

NPA, 2010. Regional Profile of Health Service/Nutrition and Water and Sanitation Coverage Government Report.

O'Neil, R., Parke, R. D., \& McDowell, D. J., 2001. Objective and subjective features of children's neighborhoods: Relations to parental regulatory strategies and children's social competence. Journal of Applied Developmental Psychology, 22, 135-155.

Parsons, T. \& Bales, R. F., 1955. Family, Socialization and Interaction Process. New York:

Oxford Dictionaries.com available at http://oxforddictionaries.com/definition/english/vagrant

Patterson, G. R., DeBaryshe, B. D., \& Ramsey, E., 1989. A developmental perspective on antisocial behavior. American Psychologist, 44, 329-335.

Preeti, B., 2010. The Lost Childhood of Street Children in Nepal, M.A Thesis, Wichita State University, Nepal.

Prince, A., 2006. Factors Related to the Street Children Phenomenon in Major Towns in Sierra Leone: A Comparative Study of the City's Street Children and Children in Normal Family Homes. Ph. D. Dissertation, St. Clements University, Sierra Leone, p.80.

Raffaelli, M., 2000 Gender differences in Brazilian street youth's family circumstances and experiences on the street. Child Abuse and Neglect, 24 (11), 1431-41.

Regassa Aboma,2001. Areal, Sectoral, and Subsectoral Distribution of NGO Projects in Oromia.Finfinne.

Ruparanganda, W., 2008.The Tragedy of Procrastinating? A Case Study of Sexual Behavior Patterns of Street Youth of Harare, Zimbabwe: In the Era of HIV and AIDS Pandemic.Unpublished doctoral thesis, University of Zimbabwe, Harare, Zimbabwe.

Samson, M., 2010.The Self-Image of Adolescent Street Children in Harare.M.A. Thesis,University of Zimbabwe, Harare, Zimbabwe.

Scanlon, T., 1998.Street children in Latin America.British Medical Journal, 316 (7144), 1596-600.

Shimelis Kassa, 2015. The Situation of Street Children in Urban Centers of Ethiopia and the Role of NGO in Addressing their Socio-Economic Problems: The Case of Hawassa City. Arbaminch University, Ethiopia.

Silva, T. L., 1996. Community Mobilization for the Protection and Rehabilitation of Street Children.Proceedings International Conference on Street Children (ICSC' 96). Jakarta: DepartemenSocialRepublik Indonesia.

Solomon Sorsa, TesifayeKidanemariam, LopisoErosie, 2002. Health Problems of Street Children and Women in Awassa, Southern Ethiopia.Ethiopian Journal of Health Development, 16 (2): 129-137.

Sweta. S, Georgina, G. Josephine, V., 2005. Youth on the Streets: The Importance of Social Interactions on Psychosocial Well-Being in an African Context. 
The Criminal Code of the Federal Democratic Republic of Ethiopia Proclamation No.414/2004

The Vagrancy Control Proclamation, Proclamation NO. 384/2004

Theis, Joachim, 2004. Promoting a Right Based Approach: Experiences and Ideas from Asia and the Pacific. Stockholm: Save the Children Sweden.

The Protection Project, 2005. Human Rights Report on Trafficking in Persons, Especially Women and Children, Washington D.C.

UMP, 2000.Street Children and Gangs in African Cities: Guidelines for Local Authorities. Urban Management Program Working Paper Series 18.

UNICEF (2000). Children Working on the Streets of Ethiopia: A UNICEF Report. https://www.unicef.org/evaldatabase/files/ETH 2000 800.pdf

UNICEF (2001). Evaluation Zim 2001/805, A Study on Street Children in Zimbabwe. New York. UNICEF. Available from https://www.unicef.org/evaldatabase/index_14411.html

UNICEF, 2002. Poverty and Exclusion among Urban Children: United Nations Children's Fund Innocent Research Center Florence, Italy.

UNICEF, 2005. The State of the World's Children 2005: Childhood under Threat, New York, United States.

UNICEF. 2006. The State of the World's Children 2006: Excluded and Invisible, New York, United States.

UNICEF, 2007.The UNICEF Protection, Rehabilitation and Prevention of Street Children and Street Mothers Project, Addis Ababa.

Valois, R. F., MacDonald, J. M., Bretous, L., Fischer, M. A., \&Drane, J., 2002. Risk factors and behaviors associated with adolescent violence and aggression. American Journal of Health Behavior, 26, 454-464.

Vanderschueren, Franz, EmielWegelin, and KadmielWekwete, 1996. Policy Program Options for Urban Poverty Reduction: a Framework for Action at the Municipal Level. Washington. D.C: UNDP.

Wandersman, A., \& Nation, M., 1998. Urban neighborhoods and mental health: Psychological contributions to understanding toxicity, resilience, and interventions. American Psychologist, 53, 647-656.

Ward CL, Seager JR., 2010. South African Street Children: A Survey and Recommendations for Services. Development Southern Africa 27: 85-100.

West, A., 2005. International Policy Lessons and Best Practices for the Protection of Vulnerable Children in China. Paper Presented at the First International Forum on Children's Development in China, Beijing, China on $29-31$ October 2005.

Yemane Beyene, 1995. Health and social problems of street children in Nazareth town.

Zena A \& Aneth K (2010). Coping Strategies Used by Street Children in Time of Illness. Dareselaam, Tanzania. 